\title{
Sustainability and the common good: Catholic Social Teaching and 'Integral Ecology' as contributions to a framework of social values for sustainability transitions
}

\author{
Ian Christie ${ }^{1} \cdot$ Richard M. Gunton $^{2} \cdot$ Adam P. Hejnowicz $^{3}$
}

Received: 27 July 2018 / Accepted: 3 April 2019 / Published online: 4 May 2019

(c) The Author(s) 2019

\begin{abstract}
It is widely acknowledged that the large-scale and long-term transitions needed to mitigate climate change and to implement policies for sustainable development within planetary boundaries require significant shifts in values and behaviours. Consequently, there is increasing interest in the processes through which major societal transitions for sustainability can occur through peaceful cooperation and widespread embrace of pro-environmental values, and the values associated with the broad concept of sustainability such as care for the interests of future generations and concern for the poor. This encompasses the search for compelling narratives to frame the process and goals of change and the need for the fostering of virtues and ethical frameworks of identity and practice that can underpin advocacy and change for sustainability. This requires drawing on richer sources of values and ethics. We suggest that important resources can be found in religious, as well as secular traditions of social values and ethical analysis. While major religions have begun to reflect environmental concerns and sustainability goals in their theology and praxis, with immense potential and actual influence over value and behaviours, little research has explored the impacts and implications of this development; nor indeed, the intellectual stimulus and social capabilities they can offer to secular thinkers and practitioners in sustainable development. In particular, we argue that there is a need to consider the affinities between secular sustainability frameworks for ethics and policy and the concepts of Catholic Social Teaching (CST) on the Common Good, recently updated by Pope Francis to integrate ecological concern and a call for universal 'ecological conversion' and cooperation. We outline the key features of CST and the Pope's new 'Integral Ecology' framework and identify affinities, in particular, with Elinor Ostrom's system of design principles for sustainable management of commons. We conclude with suggestions for research to investigate the interrelationships of the Integral Ecology reframing of CST with initiatives for transformational change in values and practices for sustainability.
\end{abstract}

Keywords Pluralism · Sustainable development · Social values $\cdot$ Faith $\cdot$ Common good $\cdot$ Christianity

\section{Introduction}

Handled by: Carena van Riper, University of Illinois at UrbanaChampaign, USA.

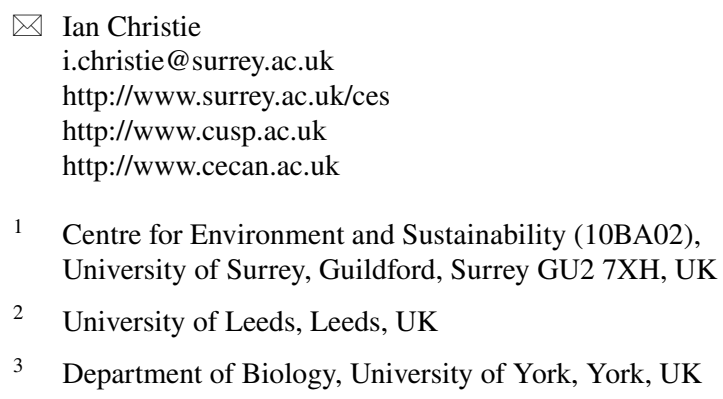

2 University of Leeds, Leeds, UK

3 Department of Biology, University of York, York, UK

There is widespread acknowledgement that the transitions needed to achieve sustainable development within 'planetary boundaries' (Steffen et al. 2015) require major political, technological and financial changes that will both depend on and generate significant shifts in values and behaviours. For example, Kendal and Raymond (2018, this issue) draw on different epistemic communities to offer a framework to help understand value-change pathways. Clearly, there is growing interest in the ways in which major societal transitions towards sustainability can be enabled via peaceful cooperation and democratic 
processes (Messner and Weinlich 2016; Smith 2017). Part of this enabling process concerns exploring compelling 'narratives' to communicate the purpose of such changes (Adams 2016; Evans 2017), alongside fostering ethical frameworks that can facilitate progress towards advocacy and change for sustainability (e.g. Curren and Metzger 2017; Lane 2017; Robeyns 2017). Arguments for an explicit shared ethical framework, or compatible plural frameworks, to promote values and behaviours aligned to the principles of sustainable development, have been central to the sustainability agenda, and is stated plainly in the Brundtland Report Our Common Future (WCED 1987), which refers to the 'overriding' imperative of meeting the needs of the poor, and for deep change in the values that guide our consumption:

...sustainable development requires the promotion of values that encourage consumption standards that are within the bounds of the ecological possible and to which all can reasonably aspire.

The principles of sustainable development originally outlined by Brundtland and expanded upon in the intervening decades (e.g. Sachs 2015) concern the recognition of foundational goods and values held in common. By recognizing a universally held common set of goods and values sustainable development discourse aims to realize a 'common future' for our 'common home'. The pursuit of that aim has two implications: (1) that we can identify a universal means of cooperating that allows us to navigate the plurality in human value systems, and (2) that there is a fundamental suite of requirements, captured in the notion of the common good that underpins human prosperity.

This begs the question, what can be the basis for global cooperation for the common goods of sustainability? One answer is that a single non-religious framework is needed, as illustrated by the UN Declaration on Human Rights or by the UN Global Goals for Sustainable Development, rooted in secular ethical frameworks such as the Capabilities Approach (Nussbaum 2011). However, arguably such a monolithic approach fails to acknowledge the geographical and historical pre-eminence of faith-based values and beliefs, which have a major and growing presence in societies worldwide. In the West, sustainable development debates have been largely conducted in secular terms, with little acknowledgement of the role potentially played by religious faiths as major social systems offering narratives, ethics and practices that can give powerful expression and support to value shifts and behavioural changes. In the light of these considerations, the role of religions ought to be integrated into analyses of value shifts. Moreover, there is great potential for religious framings to shape mechanisms for value-based influences on environmental behaviours, as discussed in this volume by Kendal and Raymond (2018) and van Riper et al. (2018a).
Historically at least, religious ethics are central to moral discourse. Adopting the notion of social values advanced in Kenter et al. (2015), in particular, their account of shared values as 'implicit, communal or public values... that are brought forward through deliberative social processes' (ibid, p. 88); and of social values as common principles and 'the values held in common by a group, community or society' (ibid., p. 88), we argue that religious faiths have long offered important framings of social values. This insight, although absent from Kenter's et al. (2015) analysis of social values recognises the historical role of religions as the dominant source of sense-making narratives, codes of conduct and debates about flourishing and suffering. From that perspective, faith traditions have provided a foundational framework in which a large proportion of humanity has located and interpreted meaning and purpose, from the ultimate questions of life to the domestic scale of social relations. They have been key sources of 'thick' ethical reflection, teaching, formation and judgement about what matters in our relationships, goals and behaviour towards one another. For instance, as Sayer (2011) notes, we are 'beings for whom things matter'.

Religious faiths today are not the only lens through which human beings are capable of making sense of what matters to us; nor does the moral diversity underpinning religious faiths always translate into social norms and cultural behaviors that are conducive and beneficial to human wellbeing and ecological flourishing. That said, religions are undeniably a major part of the historical experience of sensemaking and moral development across cultures. As Ives and Kidwell note (2019, this issue), there has been growing interest over recent years in the potential role of religions in sustainable development. This reflects the sheer scale of religious allegiance of varying kinds: we have had largely secular sustainability movements and discourses, but live in a predominantly religious world, in which over $80 \%$ of the population has some form of religious affiliation, and where the membership of major faiths is set to increase to midcentury and beyond (Pew Research Center 2015a). Transitions towards sustainable development cannot ignore the massive demographic, cultural and political presence of faith institutions and communities. There has also been increasing recognition within religious institutions and communities, especially Christian ones, of the scale of the planetary challenges of unsustainable development and the need for a major transition.

Perhaps the most striking example of this development within the faith traditions and communities came in 2015, with the publication by Pope Francis I of his Encyclical Letter on climate change, ecological degradation and the need for 'ecological conversion', Laudato Si' (Pope Francis 2015). This was followed by, and may well have contributed to, announcements on climate action from other major 
faiths. ${ }^{1}$ The publication of the Laudato Si is part of a rich heritage of Catholic Social Teaching (CST) and examination of the common good. In this paper, we explore the relevance of CST for sustainable development, a perspective that is largely absent from academic and policy discourse, but which we argue is significant because of the following factors:

1. the rising interest from secular thinkers and practitioners in the ideas associated with the common good as theorized in CST and practiced in faith institutions;

2. the centrality of CST and the idea of the Common Good to Pope Francis's Encyclical Letter Laudato Si', on 'care for our common home', addressed to the whole world and not only to the Roman Catholic faithful; ${ }^{2}$

3. important affinities between CST and secular frameworks for ethical deliberation and understanding of social values and practice for sustainability.

To be clear, our aim is not to recommend CST in particular and Roman Catholicism in general over other traditions, nor to suggest that secular frameworks of ethics be replaced by it (or by any religious framework). Nor do we claim that the Catholic Church as either an institution or a demographic has an exemplary record in applying CST in practice. Rather, we aim to highlight reasons for taking CST and its concept of the Common Good seriously in relation to sustainability, and to identify under-appreciated affinities with secular frameworks of understanding and ethical analysis.

The structure of the paper is as follows. First, we provide a brief outline of the historical conceptions of the Common Good and Sustainable Development and Sustainability, providing the background context upon which the rest of the paper's core ideas are then developed. Second, we set out the relevance of the idea of the Common Good for sustainable development, and the large-scale shifts in values and behaviours needed to help accelerate processes of cooperation for systemic change. We highlight the under-explored potential for secular proponents of sustainable development to draw on major religious traditions whose ethical and social values might turn out to align with and enrich those of sustainable development thinkers over recent decades. Third, we outline the key features of CST and of its latest variant-Integral Ecology_proposed by Pope Francis. Fourth, following this exposition, we consider the affinities between Integral

\footnotetext{
${ }^{1}$ For example, Islamic scholars worldwide (http://www.ifees.org.uk/ declaration/); and the 2015 Lambeth Declaration on climate action led by the Archbishop of Canterbury (see http://www.cimer.org.au/ documents/lambeth-declaration-on-climate-change.pdf).

${ }^{2}$ Laudato $\mathrm{Si}$ has had a notably positive reception from secular audiences worldwide (e.g. Guardian Editorial 2015; Nature Editorial 2015).
}

Ecology and secular frameworks, noting in particular an under-researched set of parallels between the CST understanding of the common good and the design principles for sustainable management of commons proposed by Elinor Ostrom and her collaborators (Ostrom 1990; Cox et al. 2009). We conclude with brief discussion of possible directions for future research into the interaction of CST with secular and religious communities and institutions.

\section{Introducing the 'Common Good'}

Notions of the common good have a long and varied history in Western intellectual thought. For example, the Greek philosopher Aristotle advanced the idea of koinei sympheron or 'common interest' in relation to 'right' and 'wrong' constitutions. Almost 2000 years later in seventeenth century England the Enlightenment thinker John Locke proposed the notion of the 'Public good of the people', which he connected to the peace and security of society, while the eighteenth century Swiss radical Jean-Jacque Rousseau referred to le bien commun which is linked to the 'general will' of the people. More recently, the American political philosopher John Rawls set forth in his Theory of Justice that the Common Good is "certain general conditions that are [...] equally to everyone's advantage"-which clearly equates the common good with aspects of social justice (Diggs 1973).

In the Christian tradition, the earliest references to the idea of the Common Good are said to be found in the Epistle of Barnabas (70-132 CE), with further expansion and codification by St Augustine in The City of God, where the Common Good is framed as individual flourishing as part of wider society. This differs distinctly from the view developed by St Thomas Aquinas, which was heavily influential in the Christian Church during the Late Medieval Period, which defined the ultimate common good as the fruitio divina or 'the eternal fruition of the divine Being' (Dupré 1993). In contemporary thought, and connected to social values, the common good comprises a family of concepts concerned with the idea of 'goodness' in the sense of virtue, rather than 'rightness' in the sense of a norm. From this perspective, the Common Good is a notion of goodness related to the 'internal requirements of a social relationship'. In general discourse, the substantive view of the common good refers to the variety of shared requirements (e.g. material, cultural) that are beneficial to most or all members of a particular community; whilst the procedural view frames the common good as a set of outcomes resulting from individual and collective civic action (Stanford Encyclopedia of Philosophy 2018).

This very brief sketch of some 'secular' and Christian understandings of the common good clearly indicates that it is a multifaceted concept with no necessarily agreed 
definition but, nevertheless, has strong connections to a relational interpretation of social values as described in Kenter et al. (2015).

\section{A note on sustainable development and sustainability}

The original definition of sustainable development proposed by the Brundtland Report (WCED 1987: 43) was:

...development that meets the needs of the present without compromising the ability of future generations to meet their own needs.

Implicitly, the report recognized limits to development whilst explicitly framing development as concerned with meeting human "needs" but also, critically, emphasized both intra- and inter-generational equity and justice as the framework to achieve those sustainable ends (Adams 2009; Sachs 2015). Twenty-five years on, at the Rio +20 Summit ('The Future We Want') in 2012, the UN General Assembly adopted a more expansive definition of sustainable development (UN 2012, para. 4):

We also reaffirm the need to achieve sustainable development by: promoting sustained, inclusive and equitable economic growth, creating greater opportunities for all, reducing inequalities, raising basic standards of living; fostering equitable social development and inclusion; and promoting integrated and sustainable management of natural resources and ecosystems that support inter alia economic, social and human development while facilitating ecosystem conservation, regeneration and restoration and resilience in the face of new and emerging challenges.

The progressive view of sustainable development thus emphasizes concerns about the global economy, specifically its underlying processes and structures, and the implications economic behaviour has for social and environmental outcomes, focusing particularly on 'social interactions', 'Earth systems' and the problems of 'governance' (Sachs 2015). Sustainability, on the other hand, is seen as less overtly political in spirit and in terms of content less focused on economic growth but is nonetheless still considered a heavily normative value-laden concept frequently seen as being subsumed within the wider sustainable development discourse (Springett and Redclift 2015).

Although the concept of sustainability is inherently multidimensional, some would argue that the dominant discourse of sustainable development to emerge has been structured to promote Western hegemony through instituting neoliberal forms of capitalism and globalization (Adams 2009). As a contested notion, discourse and policy sustainable development has both radical and conservative expressions (Springett and Redclift 2015). This helps to explain the diversity of social value discourses underpinning sustainability research identified by Horcea-Milcu et al. (2019, this issue). Overall, whilst we recognize these (quite often vigorous) debates, here we use the terms sustainability and sustainable development interchangeably, acknowledging that, despite their various actualizations, at their core they are both concerned with moving society towards a model grounded in human prosperity and social-ecological flourishing.

\section{The common good for sustainability}

The idea of a globally shared human predicament and the need for a cooperative international and cross-sectoral response to it is foundational in modern accounts of sustainable development. In this vein, sustainable development frameworks devised over the past three decades have set out a range of human goods seen as basic to wellbeing and the meeting of common needs for all human beings: the UN Sustainable Development Goals are the latest such framework, aiming to 'leave no-one behind' (United Nations 2015).

From a political economy perspective, these goods range from classic 'public goods' to 'common-pool resources'. Classic public goods are defined as open to many or all (low excludability) and capable of being consumed with no detriment to others' enjoyment of them (low rivalry); whilst common-pool resources such as oceanic fisheries, present highly complex challenges of governance and distribution, as they are constituted by low excludability and (potentially) zero-sum competition and degradation of the good by consumption (high rivalry) (Ostrom 1990). Many goods included in accounts of unsustainable development and desired sustainable futures are pre-conditional: that is, they are foundational for any form of human flourishing. Clearly, policies concerning these varieties of goods cannot be separated from matters of value and norms; and indeed, there are normative public goods from which no-one ought to be excluded (O'Neill 2007).

The very nature of these 'goods' means that many of the global, regional and local challenges of unsustainable development are collective action problems-such as land use contests, loss of habitats, and destruction of wildlife (Ostrom 1990). Collective action problems persist and can become intractable because it is in the short-term interests of actors to maintain their (unsustainable) behaviour. Change depends, therefore, on a rethinking of those social and individual values that underpin and justify interests and practices. If this is not to happen through coercion of various kinds (Hardin 1968), then a critical mass of actors need to agree to cooperate, if necessary via a re-orientation 
Box 1 An ethic for sustainability

We suggest that an Ethic for Sustainability should be:

1. Universal in scope, given the global reach of problems of unsustainable development and the need for recognition of linkages between local and global scales in diagnosing problems and devising solutions

2. Capable of generating the cooperation required for dealing with multi-level collective action problems across many boundaries (Messner and Weinlich 2016; Smith 2017)

3. Capable of generating common cause over generations

4. Capable of generating 'commitment devices' (Offer 2006) for self-sacrificial and altruistic practices and an ethic of self-restraint (Maniates and Meyer 2010; Peeters et al. 2015)

5. Based on a credible anthropological account of human capacities, needs, values and desires (Raymond and Raymond 2018 this issue)

6. Based on a coherent ethical framework capable of dealing with pluralism in values (Raymond and Raymond 2018 this issue)

and mutual translation of ethical systems, values, ideas, language, metaphors, imaginaries and practices expressing what matters to them in their social relations (Sayer 2011). Such shifts are also necessary to generate and maintain relationships of trust over time (Stern and Baird 2015).

Transitions to sustainability require radical new development pathways that are not reliant solely on socio-technical innovations in infrastructure and information technologies, but also embrace, encourage and support collective action and social movements that foster fundamental revisions in value systems and behaviours (Macebo and Sachs 2015). For instance, the scale of consumption change required for adequate climate change mitigation and living within Planetary Boundaries, as estimated in recent modelling ( $\mathrm{O}^{\prime} \mathrm{Neill}$ et al. 2018), is such as to be inconceivable without major normative shifts to support transformational change in production and consumption systems and to motivate collective and individual lifestyle change. Such value shifts are indeed hard to bring about, and there is a case to be made for working within established value systems rather than attempting to change them (Manfredo et al. 2017). However, it is also clear that major shifts in ethical frameworks can and do occur within relatively short timescales and that the history of social movements is instructive for sustainability transitions (Ives and Fischer 2017). Drawing on the resources of ethical traditions and related social values for generating changes in norms and practices is widely seen as essential for sustainability transitions (Curren and Metzger 2017; Ives and Fischer 2017; Peeters et al. 2015; Voget-Kleschin et al. 2015).

Thus, we contend that the core of sustainable development is to promote a set of 'societal values' that will protect and enhance individual and societal prosperity and welfare when applied to decision-making arenas (Bolis et al. 2017) and reflected in everyday behaviours. In the light of these considerations, the common good for sustainability can be seen as an encompassing framework of shared and social values such as (after Bolis et al. 2017): 'respect for the natural environment'; 'equity and equality'; 'ethics, justice and morality'; 'altruism and sense of community'; 'consideration of all living beings'; and 'economic value as a means and not an end'. This perspective recognizes the reality of plural values and the 'sociality' of many common goods: these considerations imply the need for any common ethical framework for cooperation for sustainability to be attuned to local differences and capable of translation, as a mutually recognizable shared set of values, into many cultural traditions and contexts (Cooper et al. 2016; Gunton et al. 2017; Hejnowicz and Hartley 2018). To enable this, it seems essential to build up shared social values that offer a sense of 'grand narrative' connecting personal concerns to wider communities of interest and common cause, and supporting an ethic of cooperation and care for the future (Adams 2016; Evans 2017; Freyfogle 2017; Smith 2017).

The idea of a common good that emerges from these considerations and from the major scientific and policy frameworks for sustainable development is not a single view of a good society or a particular form of human flourishing. Rather, it is a set of acknowledged shared social and ecological preconditions for wellbeing and achievement of particular societal and personal conceptions of a good life. The idea of the common good for sustainability is also related to the generation of cooperation at multiple scales between diverse interests to secure the preconditional goods needed for flourishing (Box 1, United Nations 2015).

If Box 1 sets out a reasonable account of what sustainable development requires by way of a supporting ethic, then the question arises whether our dominant ethical frameworks are adequate to motivate and support the changes needed. Posing this question, we see in sharp relief the anthropology and ethical assumptions of the dominant political and socio-economic imaginary and policy framework in the West since Brundtland, that is to say neoliberalism (Crouch 2011). Neoliberal economics and its associated policy frameworks have been extensively criticized, especially since the financial crisis of 2007-2008, for their anthropological and ethical failings, relying as they do on misleading reductivist 'economistic' accounts of human motivations and rationality (Hodgson 2013; O’Neill 2017). 
Box 2 Key ideas of CST

1. The Common Good. This is not a totalizing vision of one shared set of values for all of society (Spencer 2018) but rather, a set of public goods that are pre-conditional for individual and collective flourishing in community, which stress the sociality between individuals and groups by emphasizing the importance of rights, duties and responsibilities as set out in the 1965 Encyclical Gaudem et Spes (see O'Brien and Shannon 2016)

2. Human dignity. This foundational idea grounds the Common Good in the uniqueness and inherent equal value of each individual in the eyes of God. Conceptually this includes the dignity of labour and the right of all to meaningful non-exploitative work

3. Solidarity has developed as a key feature of CST's vision of the Common Good (e.g. Martinez de Anguita 2012). As such, solidarity is central to CST's philosophical anthropology: it concerns the inherent sociality of human beings and their need, as flawed and dependent creatures, to live in relations of mutual care and responsibility. Each person has a unique dignity and worth, but each is also constituted as a relational being, dependent on and capable of giving to others for the achievement of mutual flourishing (Macintyre 1999)

4. Subsidiarity is a means of respecting autonomy of communities and associations intermediate between families, states and corporations, and of avoiding undue concentrations of power (O'Brien and Shannon 2016: 568). Subsidiarity has been linked by Pope John Paul II's Encyclical Centesimus Annus (1991) and Pope Benedict XVI's Encyclical Caritas et Veritate (2008) to dignity, solidarity and hierarchical communities of support and reciprocity

Whether or not neoliberal approaches to economy and policy can be revitalized and enhanced in the wake of the crises of the 2010s, it seems clear that a richer and stronger framework of social values is required to help overcome the collective action problems of unsustainable development.

\section{Catholic Social Teaching on the common good}

The analysis above hints at the potential role of religion in transitions to sustainability. The depth and reach of religious communities and institutions as generators and transmitters of shared social values are of growing interest, both within and outside communities of faiths (Ives and Kidwell 2019, this issue). There has been increasing recognition of the scale and nature of the challenge of environmental degradation among theologians, faith leaders and communities in recent years (e.g. Deane-Drummond et al. 2017; LeVasseur and Peterson 2017; Ronan 2017; see also the work of the international NGO Alliance of Religions and Conservation, www.arcworld.org).

As was clear from some responses to the Papal Encyclical Laudato Si, such as in Nature (Nature Editorial 2015), these developments have encouraged some to suppose that major religions can be recruited as potent advocates of sustainability, with injunctions from faith leaders readily translated into practical action on the ground by believers. The reality of value-action linkages and relations between faith leaders and their local and general congregations is far more complex, as discussed in this volume by Ives and Kidwell (2019). Despite these important reservations, it is apparent that sustainability research, policy and strategies for public engagement and influencing of values and practices cannot ignore the massive presence and potential of faith communities.
In this context, we suggest there is considerable value for sustainability in exploring one of the major bodies of social thought in the industrial era, namely Catholic Social Teaching. CST stems from the Roman Catholic Church's response, generally held to commence with Pope Leo XIII's Encyclical Rerum Novarum (1891), to the upheavals in societies wrought by industrial capitalism and mass urbanization (Pontifical Council for Justice and Peace 2004; O'Brien and Shannon 2016). Rerum Novarum criticized both capitalism and socialism, affirming instead forms of associational life supporting the goods of community and individual dignity, such as a living wage, and upholding values beyond those of economic utility and self-interest. This Encyclical was followed over the next century by others that built on its conception of a just economic order that respected the goods of community and the dignity of labour (O'Brien and Shannon 2016). CST's core ideas are summarized in Box 2.

CST's philosophical anthropology and ethics of the common good have attracted growing interest in recent years from politicians, thinkers and activists, notably in secular as well as religious quarters (Williams and Elliott 2010; Longley 2014; Bretherton 2015; Glasman 2015; JohnsonDeBaufre et al. 2015; Milbank and Pabst 2016; Ryan 2016; Moffat 2017; Spencer 2018). This interest is linked to the financial crisis of 2007-2008 and its aftermath of rising inequalities and imposed austerity, which has exposed fundamental weaknesses in neoliberal capitalism and policy and generated a search for remedies. There is also evidence of a rise in academic interest in the implications of CST for economic thought and policy, and the ways in which CST can gain from engagement with social science (Finn 2010, 2017; Yuengert 2017).

Despite the rise of interest in CST, there is a striking lack of attention paid to religion in sustainable development research and practice. There is no space here to investigate in depth the reasons for this neglect; however, it is telling that Mann and Wainwright (2018), after an enthusiastic account 
Box 3 Central themes of Laudato Si'

1. A review of the scientific basis for concern for 'our common home' the Earth; a theology of Creation, interpreting the Bible and Christian traditions on human relations with the natural world to advance a bio-centric as well as theo-centric view of humans as embedded in nature and dependent on it, while bearing special responsibilities for its care (Jamieson 2015)

2. An analysis of 'the human roots of the ecological crisis', offering a philosophical anthropology of unsustainable development and the crisis of 'modern anthropocentrism'

3. An account of 'integral ecology' as a new vision of CST incorporating ecological concern and a revised theology of care for creation into the established accounts of the common good, solidarity, human dignity, subsidiarity, and the priority of concern for the poor

4. Broad recommendations for policy and partnerships at all levels, contributing to a large-scale process of 'ecological conversion' and 'ecological education'

of Laudato $\mathrm{Si}$, conclude that, ultimately, faith institutions imply 'theocracy' and restrictions on cross-cultural cooperation (ibid: 184-187). No doubt there is also widespread opposition towards the Roman Catholic Church regarding its teachings on sexuality, its denial of ordination to women, its pro-natalism, and above all the revelation of many scandals of clerical sexual abuse. The factors at work in constraining academic interest in religion and sustainability are also likely to include a widespread assumption of secularisation as inevitable, and low awareness of evidence of religious growth beyond the West and of the emerging sociological understanding of 'secular' transitions and religious 'decline' in the West (e.g. Davie 2000, 2017; Taylor 2007).

We suggest, however, that sustainability researchers and practitioners could gain by taking CST seriously. Our brief account of CST's core ideas indicates its fit with the social values and understandings that seem to be required for the transformational changes needed for sustainability. This is all the more the case in the light of Pope Francis's reformulation of CST through integration of ecological concerns in Laudato Si' (Pope Francis 2015). CST now constitutes what he terms an 'Integral Ecology', a comprehensive universal framework of social values and ethical guidance for sustainable development.

\section{Integral Ecology: Pope Francis's expansion of CST and Common Good teaching}

Laudato $S i$ is a remarkably wide-ranging and ambitious text, which can be seen as an integration of CST with secular understandings of sustainability and environmental crisis (Box 3).

The Encyclical is theologically significant for Catholics in particular and Christians in general in its interpretation of the Biblical texts on human 'dominion' over creation and the non-human world as requiring an ethic of humility, stewardship and care, in the context of a human embeddedness in and dependence on the natural world. This resonates with debates in environmental sustainability discourse that increasingly advance the importance of adopting a stewardship approach in appraising and managing human-nature interactions (West et al. 2018). It also marks a shift towards an ecological ethic and tradition of Christian spirituality associated with St Francis. This echoes the constructive ending to Lynn White's (1967) otherwise scathing critique of mainstream Christian theology and practice, which he accuses of interpreting God's gift of human 'dominion' over the Earth as license for ecological domination and destruction. A substantial literature has developed debating the theological implications of the Encyclical and its potential to generate change within the Catholic world (e.g. Cobb and Castuera 2017; Miller 2017a, b). However, it is the reach of the Encyclical beyond the Roman Catholic faithful that is of significance for sustainability researchers and practitioners. The Pope addresses the Encyclical to "all people of good will" (Pope Francis 2015, para. 63), not only to the 1.2 billion members of the Roman Catholic Church. The cosmopolitan appeal of the Encyclical is enhanced, as Iheka (2018) argues, by Francis's emphasis on concern for the poor, his call for dialogue and collaboration on sustainability across faiths and secular-faith boundaries, and by the range of scientific evidence and policy issues referenced in the Encyclical.

The Encyclical can thus be seen as intended to engage CST's Universalist vision with other ethical systems, secular and religious, to generate conversations and collaborations in which the theology and Christian ethics of CST, reconceived as IE, can be translated into secular and other religious frameworks, and can also learn from them. In his exploration of the 'Cosmic Common Good', Scheid (2016) identifies parallels and grounds for shared understanding and ethical action between religious concepts of the common good worldwide. There are resonances too with Protestant philosophical anthropology, as in the case of postwar Dutch 'Reformational Thought' now being used as the basis for innovative approaches to environmental valuation and decision-making (Gunton et al. 2017).

The IE vision also has strong connections to the secular frameworks of modern virtue and care ethics (Macintyre 1999; Clowney 2014; Groves 2012). The vision and programme of IE has strong affinities, for example, with the 
Box 4 Ostrom's design principles for commons management

Design Principles for effective management of common-pool resources, as modified by Cox et al. (2009), based on the list developed by Ostrom (1990):

(1a) Clearly defined user boundaries: individuals or households who have rights to withdraw resource units from the common-pool resource $(\mathrm{CPR})$ are clearly defined

(1b) Clear boundaries of resource system: the boundaries of the CPR are well defined

(2a) Congruence with local conditions: appropriation and provision rules are congruent with local social and environmental conditions

(2b) Benefits of appropriation and provision inputs are proportionate

(3) Collective-choice arrangements: most individuals affected by the operational rules can participate in modifying the operational rules

(4a) Monitoring of users: monitors who are accountable to the users monitor the appropriation and provision levels of the users

(4b) Monitoring the resource: monitors who are accountable to the users monitor the condition of the resource

(5) Graduated sanctions: appropriators who violate operational rules are likely to be assessed with graduated sanctions (depending on the seriousness and the context of the offence) by other appropriators, by officials accountable to the appropriators, or by both

(6) Conflict-resolution mechanisms: appropriators and their officials have rapid access to low-cost local arenas to resolve conflicts among appropriators or between appropriators and officials

(7) Minimal recognition of rights to organise: the rights of appropriators to devise their own institutions are not challenged by external governmental authorities

(8) Nested enterprises: appropriation, provision, monitoring, enforcement, conflict resolution, and governance activities are organised in multiple layers of nested enterprises

Capabilities Approach (CA) to universal human needs for flourishing (e.g. Nussbaum 2011; Rauschmeyer et al. 2011; Crocker 2016; Peeters et al. 2015; Holden et al. 2018). In particular Gough's (2017) discussion of CA and the need for it to be based on a universal conception of human need and flourishing, a concept of 'relational wellbeing', has resonance with the analysis in Laudato Si'.

A final affinity, which has so far attracted little or no attention, but which is potentially significant in the generation of cooperation and new ethical approaches to policy design and assessment for sustainability, is between the CST tradition and the commons framework of the Nobel Economics Laureate Elinor Ostrom and her collaborators, which we explore in the next section.

\section{Commons as covenant: Integral Ecology's affinities with Ostrom's design principles}

As noted earlier, the collective action problems associated with open-access environments that are easily depleted are complex and foundational to challenges of unsustainability. Ostrom (1990) and her collaborators (Cox et al. 2009; Vollan and Ostrom 2010) elaborated a set of design principles for the sustainable management of common-pool resources (Box 4). Ostrom's proposed approach to such problems is the translation of a set of universal design principles into action appropriate to local conditions. The framework has been shown to be robust (Cox et al. 2009) and a large critical literature has developed to test it and modify it (e.g. Araral 2013). It is reasonable to see this evolving framework as one of the most significant contributions to date to the social science and practice of sustainability. As such, links between it and a framework such as IE/CST are of great interest. We suggest that there are important affinities between Ostrom's framework and IE/CST which have not been explored, even in the literature where explicit efforts are made to connect eco-theology, common good scholarship and thinking on the commons (e.g. Johnson-DeBaufre et al. 2015; Bretherton 2015; Edenhofer and Flachsland 2017; Hart 2006).

Several of the design principles, taken either individually or collectively, may be linked to the core principles of CST and IE. The parallels that we suggest as worthy of further elaboration and development are these:

1. The commons framework is rooted in a version of $s u b$ sidiarity, requiring rights for communities to organize themselves within a nested system of supportive enterprises and governance (Design Principles 1, 2, 7 and 8). This connects CST also to the broader analysis by Ostrom (2010) of the need for polycentric governance to underpin and generate effective action for sustainable development.

2. The commons design principles point to the importance of governance by a defined community whose values, by implication, should support the solidarity required to maintain a common-pool resource (Design Principle 3).

3. The commitment to sustaining commons requires an implicit or explicit ethic of care of the resource and its governance system for future generations - an ethos of relational concern that extends beyond the community of resource users into an indefinite future (O'Neill 1993, 2017). In the context of CST and its roots in Biblical interpretation, this can be characterized as a universalizable version of the Judeo-Christian religious idea of 
covenant: that is, the engagement of a community in a sacred and enduring relationship with a transcendent Good, in this case God and God's gift of a created order, placing obligations on the community to its members and to that larger order (Northcott 2007, 2015).

4. We suggest that the common-pool resource design principles point to the importance of particular concepts of ethics to commons governance, which are also fundamental to the development of CST. These include the cultivation of virtues via communities of practice and mutual dependence (Macintyre 1999). The health of the commons and the avoidance of free-riding requires systems of sanctions, mutual monitoring and conflictresolution (Design Principles 4-6, elaborated by Ostrom 1990; Cox et al. 2009). These can be seen as institutions that internalize an ethos of mutuality and virtues of self-restraint for the common good. The purpose of commons management is not just to generate a sustained and sustainable flow of services from the resource base but also to secure mutual trust in the context of mutual inter-dependence. It is thus a generator of, and a system dependent on, shared social values.

These affinities, we suggest, indicate potential for translation of CST concepts into secular frameworks of ethics and governance for sustainability, and for ideas from the latter systems to be translated into terms intelligible to CST. This highlights the potential-fundamental to the Pope's call for worldwide conversation and partnership-for cooperation between those upholding differing universalist frameworks, whether secular or religious, for understanding and acting on the sustainability challenge.

A practical expression of this potential can be found in pluralistic approaches to environmental valuation and land use planning dilemmas (e.g. Hejnowicz and Rudd 2017). Furthermore, Gunton et al. (2017) have begun to develop a pluralistic approach to environmental valuation based on values and concepts emerging from Dutch Calvinist 'Reformational Philosophy', which can be translated into secular terms. We suggest that CST values and categories can be applied in similar ways for deliberative policy appraisal and evaluation processes that foreground the ethical challenges of sustainability (see Gorringe 2011). They could also be integrated with similar approaches using Ostrom's design principles as a method for policy appraisal and evaluation and other emerging frameworks for pluralistic ethics-based deliberation (Christie et al. 2019, forthcoming, see also van Riper et al. 2018b).

\section{Implications for sustainability science and practice}

We have highlighted the widespread recognition that the scale of change needed for sustainability transitions goes well beyond what can be generated either by greening of growth or by piecemeal approaches to 'behaviour change' (Capstick et al. 2015; Jackson 2017; Jackson and Smith 2018). Harnessing our most powerful ethical traditions and related social values for generating changes in norms and practices is essential. There is a need for representation and acknowledgement of religious values and frameworks in this context, given that we live in a largely religious world that must find ways to generate common cause and cooperative action at all levels for sustainability transitions. Christian traditions in general, and CST in particular, can be seen to underpin or at least to be compatible with secular approaches to ethical reasoning and action for sustainability: we have noted in particular the affinities with the commons management design principles proposed by Ostrom and her collaborators (Cox et al. 2009). This indicates large scope for collaboration on the basis of translatability of differing Universalist frameworks of valuation and sustainable welfare.

There are risks in the engagement with religious frameworks and institutions in relation to sustainability, as noted by Ives and Kidwell (2019) in this volume. These include the problem of taking an instrumental approach to religion as an aid to an essentially secular vision of societal transformation. Another risk is over-optimism about the speed and reliability of transmission of promulgated values from religious leaders to believers and into behaviour. There is evidence of ideological resistance to the Encyclical from many US Catholics and evangelicals (Pew Research Center 2015b), possibly indeed reinforced by the positive reception it has had from many secular liberals and environmentalists in business and civil society. That said, a considerable re-framing of religious values and worldviews to encompass environmental concerns and values has already taken place, and the major faiths have resources and networks - entry and leverage points into cultures (Koehrsen 2015) - that could generate new cultural imaginaries and influence everyday practice in ways that promote sustainability.

Clearly, numerous questions arise concerning CST and the role of faiths in the generation of shared social values for sustainability transitions. For instance, what has been the impact of Pope Francis's recasting of CST as IE on Catholic institutions and communities in different countries and contexts? Has Laudato Si' begun to influence secular and non-RC religious actors? Which ones, how, and with what effect? What are the prospects for, and processes 
to enable, the dialogues and 'ecological conversion' called for by the Pope? How far are CST/IE values genuinely 'shared' and 'social' (Kenter et al. 2015) among Catholics, and how do they inform and conflict with personal values and expressions of faith and commitments? Such questions also highlight the fact that in arguing for a greater dialogue and co-alignment between faith-based traditions and sustainability, in our case articulated through the lens of CST, we need to be cognizant of how we navigate the plurality of social values within and between CST and sustainability theory and practice. We need to take account of areas of compatibility and conflict, and adopt sufficient humility to avoid embedding or entrenching power asymmetries in the social values underpinning sustainability transitions. Such considerations are also important in terms of understanding how a faith-informed social-values foundation to sustainability promotes and fosters environmental behaviours through value awareness and activation.

In the light of the analysis above and the gaps in the emerging literature connecting CST, Integral Ecology and secular frameworks for sustainable development, we propose that there would be value in:

1. Detailed investigation of the reception and operationalization of the Pope's Integral Ecology teaching on CST by Roman Catholic communities and their partners across faith boundaries;

2. Further work on the translation of Integral Ecology in Roman Catholic organizations' partnerships with other religious and secular organizations, such as corporations aiming to be leaders in sustainable business strategies and corporate responsibility, and in relation to interpretation and implementation of the UN Global Goals for Sustainable Development;

3. Case studies and experiments in adapting CST categories for deliberative policy appraisal and evaluation processes that foreground ethical challenges of SD, and integrating these with other emerging frameworks for pluralistic ethics-based deliberation (e.g. Gunton et al. 2017), in particular approaches to valuation and values analysis that build on Ostrom's commons management principles and framework for understanding the dynamics of social-ecological systems (van Riper et al. 2018b).

In conclusion, we endorse Ives' and Kidwell's (2019) suggestion in this volume that "further research on social values for sustainability must recognise and accommodate how religion as an institution intersects with social values." We suggest that in the spirit of the Pope's Encyclical, secular academic researchers, policymakers and advocates of sustainability and environmental values should be open to insights and framings from CST/IE and from the faith traditions in general. The latter are indeed increasingly open to rethinking and innovative action on the basis of their rediscovery of deep values and narratives in their texts and practices in the light of sustainability science and rising concern over our collective unsustainable impacts on the Earth.

Open Access This article is distributed under the terms of the Creative Commons Attribution 4.0 International License (http://creativeco mmons.org/licenses/by/4.0/), which permits unrestricted use, distribution, and reproduction in any medium, provided you give appropriate credit to the original author(s) and the source, provide a link to the Creative Commons license, and indicate if changes were made.

\section{References}

Adams WM (2009) Green development: environment and sustainability in a developing world. Routledge, London

Adams M (2016) Ecological crisis, sustainability and the psychosocial subject: beyond behaviour change. Palgrave Macmillan, London

Araral E (2013) Ostrom, Hardin and the commons: a critical appreciation and a revisionist view. Environ Sci Policy 36:11-23

Bolis I, Moroika SN, Sznelwar LI (2017) Are we making decisions in a sustainable way? A comprehensive literature review about rationalities for sustainable development. J Clean Prod 145:310-322

Bretherton L (2015) Resurrecting democracy: faith, citizenship, and the politics of a common life. Cambridge University Press, Cambridge

Capstick S, Lorenzoni I, Corner A, Whitmarsh L (2015) Prospects for radical emissions reduction through behavior and lifestyle change. Carbon Manag 5:4

Christie I et al (2019, forthcoming) 'C3E: an approach to policy appraisal and evaluation based on Ostrom's design principles for commons management'. CECAN Working Paper. University of Surrey: Centre for Evaluation of Complexity across the Nexus (CECAN)

Clowney D (2014) Collective environmental virtue. Environ Values 23(3):315-333

Cobb J, Castuera I (eds) (2017) For Our Common Home: process-relational responses to Laudato Si'. Process Century Press, Anoka

Cooper N, Brady E, Bryce R, Steen H (2016) Aesthetic and spiritual values of ecosystems: recognising the ontological and axiological plurality of cultural ecosystem "services". Ecosyst Serv 21:218-229

Cox M et al (2009). Design principles are not blueprints, but are they robust? A meta-analysis of 112 studies, Working Paper. Lincoln Institute of Land Policy

Crocker D (2016) Ethics of global development: agency, capability and deliberative democracy. Cambridge University Press, Cambridge

Crouch C (2011) The strange non-death of neo-liberalism. Polity Press, Cambridge

Curren R, Metzger E (2017) Living well now and in the future: why sustainability matters. MIT Press, Cambridge

Davie G (2000) Religion in modern Europe: a memory mutates. Oxford University Press, Oxford

Davie G (2017) Religion in public life: levelling the ground. Theos/ Edward Cadbury Centre for the Public Understanding of Religion, London

Deane-Drummond C, Bergmann S, Vogt M (eds) (2017) Religion in the anthropocene. Cascade Books, Eugene

Diggs BJ (1973) The common good as reason for political action. Ethics 83(4):283-293 
Dupré L (1993) The common good and the open society. In: Hollenbach D, Douglas B (eds) Catholicism and liberalism. Cambridge University Press, Cambridge

Edenhofer O, Flachsland C (2017) 'Laudato Si': concern for our global commons. In Miller V (ed) op.cit.

Evans A (2017) The myth gap. Eden Project Books, London

Finn D (ed) (2010) The true wealth of nations: Catholic social thought and economic life. Oxford University Press, Oxford

Finn D (ed) (2017) Empirical foundations of the common good. Oxford University Press, Oxford

Freyfogle E (2017) A good that transcends: how US culture undermines environmental reform. University of Chicago Press, Chicago

Glasman M (2015) The good society, Catholic social thought and the politics of the common good. In: Geary I, Pabst A (eds) Blue labour: forging a new politics. IB Tauris, London

Gorringe T (2011) The common good and the global emergency. Cambridge University Press, Cambridge

Gough I (2017) Heat, need and human greed: climate change, capitalism and sustainable wellbeing. Edward Elgar, Cheltenham

Groves C (2012) Care, uncertainty and intergenerational ethics. Palgrave Macmillan, Basingstoke

Guardian Editorial (2015) The Guardian view on Laudato Si': Pope Francis calls for a cultural revolution. 18 June. https://www.thegu ardian.com/commentisfree/2015/jun/18/guardian-view-on-lauda to-si-pope-francis-cultural-revolution. Accessed 12 Apr 2019

Gunton R et al (2017) Beyond ecosystem services: valuing the invaluable. Trends Ecol Evol 32(4):249-257

Hardin G (1968) The tragedy of the commons. Science 162:1243-1248

Hart J (2006) Sacramental commons: Christian ecological ethics. Rowman and Littlefield, Lanham

Hejnowicz AP, Hartley S (2018) New directions: a public goods approach to agricultural policy post-Brexit. CECAN, Guildford; YESI, York

Hejnowicz AP, Rudd MA (2017) The value landscape in ecosystem services: value, value wherefore art thou value? Sustainability 9:850

Hodgson G (2013) From pleasure machines to moral communities: an evolutionary economics without homo economicus. University of Chicago Press, Chicago

Holden E et al (2018) The imperatives of sustainable development: needs, justice, limits. Earthscan/Routledge, London

Horcea-Milcu IA, Abson DJ, Apetrei CI et al (2019) Values in transformational sustainability science: four discourses for change. Sustain Sci. https://doi.org/10.1007/s11625-019-00656-1

Iheka C (2018) Pope Francis' integral ecology and environmentalism for the poor. Environ Ethics 39:243-259

Ives C, Fischer J (2017) The self-sabotage of conservation: reply to Manfredo et al.: conservation and value change. Conserv Biol 31(6): 1483-1485

Ives C, Kidwell J (2019) Religion and social values for sustainability. Sustain Sci. https://doi.org/10.1007/s11625-019-00657-0

Jackson T (2017) Prosperity without growth: foundations for the economy of tomorrow, 2nd edn. Routledge, London

Jackson T, Smith C (2018) Towards sustainable lifestyles: understanding the policy challenge. In: Lewis A (ed) Cambridge handbook of psychology and economic behaviour. Cambridge University Press, Cambridge

Jamieson D (2015) Why Laudato Si' matters. Environ Sci Policy Sustain Dev 57(6):19-20

Johnson-DeBaufre M, Keller C, Ortega-Ponte E (eds) (2015) Common goods: economy, ecology and political theology. Fordham University Press, New York

Kendal D, Raymond CM (2018) Understanding value shifts in response to individual, demographic and social-ecological change. Sustain Sci (this issue)
Kenter JO, O'Brien L, Hockley N, Ravenscroft N, Fazey I, Irvine KN, Reed MS, Christie M, Brady E, Bryce R, Church A, Cooper N, Davies A, Evely A, Everard M, Fish R, Fisher JA, Jobstvogt N, Molloy C, Orchard-Webb J, Ranger S, Ryan M, Watson V, Williams S (2015) What are shared and social values of ecosystems? Ecol Econ 111:86-99

Koehrsen J (2015) Does religion promote environmental sustainability? Exploring the role of religion in local energy transitions. Soc Compass 62:296-310

Lane M (2017) A new professional ethics for sustainable prosperity. Paper in CUSP essay series on the ethics of sustainable prosperity. Centre for Understanding of Sustainable Prosperity, University of Surrey, Guildford

LeVasseur T, Peterson A (eds) (2017) Religion and ecological crisis. Routledge, London

Longley C (2014) Just money: how catholic social teaching can redeem capitalism. Theos, London

Macintyre A (1999) Dependent rational animals: why human beings need the virtues. Open Court, Chicago

Manfredo MJ et al (2017) Why social values cannot be changed for the sake of conservation. Conserv Biol 31(4):772-780

Maniates M, Meyer J (eds) (2010) The environmental politics of sacrifice. MIT Press, Cambridge

Mann G, Wainwright J (2018) Climate Leviathan: a political theory of our planetary future. Verso, London

Martinez de Anguita P (2012) Environmental solidarity: how religions can sustain sustainability. Routledge, Abingdon

Messner D, Weinlich S (eds) (2016) Global cooperation and the human factor in international relations. Routledge, London

Milbank J, Pabst A (2016) The politics of virtue: post-liberalism and the human future. Rowman and Littlefield, London

Miller V (ed) (2017a) The theological and ecological vision of Laudato Si'. Bloomsbury, London

Miller V (2017b) Integral ecology: Francis's spiritual and moral vision of interconnectedness. In Miller (ed) op.cit.

Moffat V (ed) (2017) Reclaiming the common good. DLT, London

Nature Editorial (2015) 'Hope from the Pope'. Nature 522(7557)

Northcott M (2007) A moral climate: the ethics of global warming. DLT, London

Northcott M (2015) Place, ecology and the sacred: the moral geography of sustainable communities. Bloomsbury, London

Nussbaum M (2011) Creating capabilities: the human development approach. Belknap Press, Cambridge

O'Brien D, Shannon T (eds) (2016) Catholic social thought: encyclicals and documents from Pope Leo XIII to Pope Francis. Orbis, Maryknoll

O’Neill J (1993) Ecology, policy and politics: human well-being and the natural world. Routledge, London

O’Neill J (2007) Markets, deliberation and the environment. Routledge, London

O'Neill J (2017) 'Life Beyond Capital'. Paper in CUSP essay series on the ethics of sustainable prosperity. Centre for Understanding of Sustainable Prosperity, University of Surrey, Guildford

O’Neill D et al (2018) A good life for all within planetary boundaries. Nat Sustain 1:88-95

Offer A (2006) The challenge of affluence. Oxford University Press, Oxford

Ostrom E (1990) Governing the commons. Cambridge University Press, Cambridge

Ostrom E (2010) Beyond markets and states: polycentric governance of complex economic systems. Am Econ Rev 100:641-672

Peeters W, Dirix J, Sterckx S (2015) The capabilities approach and environmental sustainability: the case for functioning constraints. Environ Values 24(3):367-389

Pew Research Center (2015a) The future of world religions: population growth projections, 2010-2050. Pew Center, Washington. http:// 
assets.pewresearch.org/wp-content/uploads/sites/11/2015/03/ PF_15.04.02_ProjectionsFullReport.pdf. Accessed 12 Apr 2019

Pew Research Center (2015b) Catholics divided over global warming. Pew Center, Washington. http://assets.pewresearch.org/wp-conte nt/uploads/sites/11/2015/06/Catholics-climate-change-06-16full.pdf. Accessed 12 Apr 2019

Pontifical Council for Justice and Peace (2004) Compendium of the social doctrine of the Church. http://www.vatican.va/roman _curia/pontifical_councils/justpeace/documents/rc_pc_justp eace_doc_20060526_compendio-dott-soc_en.html. Accessed 12 Apr 2019

Pope Francis (2015) Encyclical letter Laudato Si' of the Holy Father Francis on care for our common home. http://w2.vatican.va/conte $\mathrm{nt} /$ francesco/en/encyclicals/documents/papa-francesco_20150 524 enciclica-laudato-si.html

Rauschmeyer F, Omann I, Frühmann J (eds) (2011) Sustainable development: capabilities, needs and well-being. Routledge, London

Raymond IJ, Raymond CM (2018) Positive psychology perspectives on social values and their applications to intentionally delivered sustainability transformations. Sustain Sci (this issue)

Robeyns I (2017) 'Freedom and responsibility-sustainable prosperity through a Capabilities Lens'. Paper in CUSP essay series on the ethics of sustainable prosperity. Centre for Understanding of Sustainable Prosperity, University of Surrey, Guildford

Ronan M (2017) Religion and the environment: twenty-first century American evangelicalism and the anthropocene. Humanities 6(4):92

Ryan B (2016) Catholic social thought and Catholic charities in Britain today. Theos, London

Sachs JD (2015) The age of sustainable development. Columbia University Press, New York

Sayer A (2011) Why things matter to people: social science, values and ethical life. Cambridge University Press, Cambridge

Scheid D (2016) The Cosmic common good: religious grounds for ecological ethics. Oxford University Press, Oxford

Smith S (2017) Modelling "the expanding circle" of cooperation towards a sustainable future. Eur J Sustain Dev 6:4

Spencer N (2018) An Anglican understanding of the common good. http://togetherforthecommongood.co.uk/viewpoints/opinionpieces/articles/an-anglican-understanding-of-the-common-good. html. Accessed 12 Apr 2019

Springett D, Redclift M (2015) Sustainable development: history and evolution of a concept. In: Redclift M, Springett D (eds)
Routledge handbook of sustainable development. Routledge, London, pp 3-38

Stanford Encyclopedia of Philosophy (2018) The common good. https ://plato.stanford.edu/entries/common-good/. Accessed 10 June 2018

Steffen W et al (2015) Planetary boundaries: guiding human development on a changing planet. Science 347:1259855

Stern MJ, Baird T (2015) Trust ecology and the resilience of natural resource management institutions. Ecol Soc 20(2):14

Taylor C (2007) A secular age. Belknap Press, Cambridge

UN (2012) The future we want: outcome document. United Nations, New York. https://sustainabledevelopment.un.org/rio20/futur ewewant. Accessed 15 Apr 2019

United Nations (2015) Transforming our world: the 2030 agenda for sustainable development. United Nations, New York

van Riper C, Winkler-Schor S, Stamberger L, Keller R, Braito M, Raymond $\mathrm{C}$ et al (2018a) Integrating multi-scale values and pro-environmental behaviour in a protected area. Sustain Sci (this issue)

van Riper C, Thiel A, Penker M, Braito M, Landon A, Thomsen J, Tucker C (2018b) Incorporating multilevel values into the socialecological systems framework. Ecol Soc 23(3):25

Voget-Kleschin L, Baatz C, Ott K (2015) Ethics and sustainable consumption. In: Reisch L, Thorgerson J (eds) Handbook of research on sustainable consumption. Edward Elgar, Cheltenham

Vollan B, Ostrom E (2010) Cooperation and the commons. Science 330(6006):923-924

WCED (1987) Our common future. Oxford University Press, Oxford

West S, Haider J, Masterson V, Enqvist JP, Svedin U, Tengö M (2018) Stewardship, care and relational value. Curr Opin Environ Sustain 35:30-38

White L (1967) The human roots of our ecologic crisis. Science 155:1203-1207

Williams R, Elliott L (eds) (2010) Crisis and recovery: ethics, economics and justice. Palgrave Macmillan, Basingstoke

Yuengert A (2017) What can economists contribute to the common good tradition? In Finn D (ed) (2017) op.cit.

Publisher's Note Springer Nature remains neutral with regard to jurisdictional claims in published maps and institutional affiliations. 